\title{
原著論文
}

\section{製品属性と消費者属性の交互作用を考慮した 製品デザインの提案}

\author{
市川 雄一朗*, 齊藤 史哲**, 石津 昌平** \\ * 東京工業大学, ${ }^{* *}$ 青山学院大学
}

\section{Proposal of the Product Design by Considering the Interactions among Product-attributes and Customer-attributes}

\author{
Yuichiro ICHIKAWA*, Fumiaki SAITOH** and Syohei ISHIZU** \\ * Tokyo Institute of Technology, 2-12-1 Ookayama,Meguro-ku, Tokyo 152-8552, Japan \\ ** Aoyama Gakuin University, 5-10-1 Fuchinobe, Chuo-ku, Sagamihara, Kanagawa 252-5258, Japan
}

\begin{abstract}
To design products with high customer satisfaction, it is necessary that the suppliers must design attractive products for some specific customers. However, designing them is not easy because customers have different preference and Kanse $i$ affects for the products. The evolution of products is not common for each customer. We propose the method for designing the products by considering the different customer's Kansei. In this paper we analyse the interaction among product-attributes (color, shape etc.) and customer-attributes (gender, age etc.) which affects customer's Kansei. Analyzing the interaction leads to designing the production which some customer categories like in common and a customer category like. In this way, this paper considers the different customer's Kansei and proposes the products which fit for the customer's Kansei.
\end{abstract}

Keywords : Kansei evaluation, Parameter design, Customer-attributes

\section{1. はじめに}

感性工学においては，消費者の持つ製品デザインに対する イメージを数值化して設計し, 反映させる技術が必要とされ ている，そこで，企業を始めとするサプライヤーにとって製 品を開発する際に消費者がどのような欲求を満たそうとして 製品を購入しているのか, どのような製品を魅力的に感じる かを把握することは重要である. 小阪 $[1]$ にあるように人 が製品に対して魅力に思う要素の一つが製品デザインである ので，消費者の視覚に訴えかける製品デザインを良くするこ とは，消費者の満足度を向上させるきっかけとなる。

しかし，消費者が好むようなデザインを提案するにあたっ て問題となってくるのは感性の個人差である, 特に, 個人差 の要因として挙げられるのが消費者属性の違いによるもので ある，製品に対する評価は消費者属性に応じて変化してしま う．顧客満足度を高める製品を生み出すためには消費者の嗜 好に合わせた製品を考えることが重要であり，そのためには 消費者属性の違いを定量化する必要がある。

消費者属性の違いを考慮する方法としては齋藤ら［2］の ように因子分析やクラスター分析を用いて消費者を層別し, 消費者ごとの特徵をつかむ方法が提案されてきている，特に 消費者属性を誤差因子や標示因子と捉えることで直積実験を 行い計画的に消費者の個人差を考慮する方法が提案されてき ている. Widiyatiら [3] では夕グチメソッドによるSN比解 析を用いて全ての消費者から共通の評価を得られる製品デザ
インを提案している．鈴木ら［4] はコンジョイント分析を 行うことで消費者の嗜好に合わせた製品デザインを分析して いる。しかし，これらの方法は消費者属性と製品属性の評価 值との関連を表すモデルでないため, 消費者属性の違いがど の程度感性評価へ影響を与えているかを定量的に把握できて いないという問題がある。

一方，高橋ら［5，，河村ら［6］は多水準系の誤差因子間の 交互作用をもつ統計モデルを提案しており，直積実験に基づ き誤差因子間および制御因子間の交互作用の影響をモデル化 している.

本研究の目的は製品属性と消費者属性の交互作用を分析す ることで，感性の個人差を生みだす要因となる消費者属性の 違いを考慮した製品デザインの方法を提案することである. 本研究では高橋や河村らの交互作用モデルにおける特性值を 感性評価值，制御因子を製品属性，誤差因子を消費者属性と することで，感性評価における製品属性と消費者属性の交互 作用を分析することを提案する。

直積実験として感性評価実験を計画することで，消費者属 性ごとや，複数の消費者属性に含まれる個人と製品属性の 交互作用を効率的にもとめることができる，本論文で提案す る製品デザインの特徵は，製品属性と消費者属性の交互作用 の分析を通して消費者属性における個人の製品評価值のばら つきを評価し,ばらつきの大きさにもとづき消費者カテゴリー を層別・選定し，選定した消費者カテゴリーに適した製品 デザインを決定することである，本研究では製品属性と消費 者属性の交互作用のモデルの定式化を行い，モデルを用いて 
感性の共通性と相違性に着目することで感性にあった製品の デザイン方法を提案する。 その上でメガネを対象とした製品 デザインの事例を示す.

\section{2. 感性の個人差を考慮した製品設計}

\section{1 製品属性と消費者属性の交互作用モデル}

本研究では, 高橋ら [5]と河村ら [6]の“多水準系の誤差因 子間の交互作用をもつ統計モデル”を用いて製品属性と消費 者属性の交互作用モデルを提案する.まず, 河村らのモデル式 の定義を示す. 特性 $y$ の平均が制御因子 $x=\left(x_{1}, x_{2}, \cdots, x_{g}\right)$ と誤差因子 $z=\left(z_{1}, z_{2}, \cdots, z_{h}\right)$ の関数 $\mu(x, z)$ で与えられている とし, データの構造には誤差項 $\varepsilon$ のあ応答モデルを想定す ると式 (2.1) のようになる.

$$
y=\mu(x, z)+\varepsilon, \quad \varepsilon \sim N\left(0, \sigma^{2}\right)
$$

制御因子および誤差因子の関係を表現する $\mu(\mathrm{x}, \mathrm{z})$ につい ては誤差因子 $z=\left(z_{1}, z_{2}, \cdots, z_{h}\right)$ とそれらの交互作用 $z_{1} \times z_{2}, \cdots$ を考慮し, 各水準を $x$ とをダミー変数と扱うことにして式 を表現すると式 (2.2)のようになる。

$$
\mu(x, z)=L(x)+D(x, z)
$$

また，誤差因子 $z$ による影響を受けない $L(x)$ を平均パート と呼び，パラメータ $\alpha$ を用いて式 (2.3) で定義される. $D(x, z)$ は誤差因子 $z$ が特性に影響を与える部分であり乘離 パートと呼ぶ。この乘離パートのことを総乘離と呼び, パラ メータ $\beta$ を用いて式 (2.4) で定義する.

$$
\begin{aligned}
L(x)= & \alpha_{0}+\sum_{i=1}^{g} \alpha_{i} x_{i}+\sum_{1 \leq i, j \leq g}^{g} \alpha_{i j} x_{i} x_{j} \\
D(x, z)= & \sum_{k=1}^{h}\left(\beta_{0}+\sum_{i=1}^{g} \beta_{i} x_{i}+\sum_{1 \leq i, j \leq g}^{g} \beta_{k i j} x_{i} x_{j}\right) z_{k} \\
& +\sum_{1 \leq k l l \leq h}^{h}\left(\beta_{k l}+\sum_{i=1}^{g} \beta_{i} x_{i}+\sum_{1 \leq i, j \leq g}^{g} \beta_{k i j} x_{i} x_{j}\right) z_{k} z_{l}
\end{aligned}
$$

高橋ら [5], 河村ら [6] では, (2.1)のモデルのyは機能 性設計に関する特性を適用した研究であったが, 本研究では 感性評価を適用して, 消費者属性の違いによる感性の違いを 活かした製品デザインを提案する，そこで，特性を感性評価 值, 制御因子を製品属性, 誤差因子を消費者属性とした交互 作用モデルを製品属性と消費者属性の交互作用モデルと呼ぶ こととする.

\section{2 モデルの優位性}

Widiyatiら［3］は製品属性と消費者属性の交互作用によ る影響を低減させることを目的としているタグチメソッドを 用いていることもあり製品属性間の交互作用や消費者属性間 の交互作用を考慮していない。つまり式 (2.2)のD(x,z)が 考慮されておらず式 $(2.1)$ にある $\varepsilon$ の一部として扱われてい る. 鈴木ら[4]ではコンジョイント分析を用いて製品属性 ごとの最適水準を求めるために製品属性と消費者属性の交互 作用を考慮しているが，製品属性間の交互作用と消費者属性
間の交互作用は誤差項として扱われている.つまり, 式 (2.4) の $\sum_{1 \leq k l \leq h}^{h}\left(\beta_{k l}+\sum_{i=1}^{g} \beta_{i} x_{i}+\sum_{1 \leq i j j \leq g}^{g} \beta_{k i j} x_{i} x_{j}\right) z_{k} z_{l}$ を式 (2.1)の $\varepsilon$ の 一部として処理している。本研究で提案する製品属性と消費 者属性の交互作用モデルはこれまで誤差項 $\varepsilon$ とて扱ってい た交互作用による影響についても分析すべき要因とすること ができるので，より詳細な分析が可能になると言える.

\section{3 製品属性と消費者属性の交互作用モデルの分析方法}

式 (2.3)，(2.4）におけるパラメータ $\alpha, \beta$ は回帰分析によ り求める。，そして，導出後変数増減法を用いることで意味の ある交互作用の分析ができる。交互作用モデルは平均パート と乘離パートで構成されており，それぞれが果たす役割は次 の通りである.

平均パート $(L(x))$ : 消費者属性の影響を受けないパートで あり，評価值を目標值へ近づける際に用いる

乘離パート $(D(x, z))$ : 消費者属性が評価值へ影響を与える パートであり，消費者ごとの評価のばらつきが製品属性と消 費者属性の交互作用という形で表現されている

特に乘離パートに着目することで，消費者属性が評価值へ 与えている影響を把握することができる。 そこで, 本研究で は消費者属性に着目し，同じ消費者属性を持つ個人の平均と 平均からの分散を総乘離や乘離度という新たな指標を用い て, 消費者属性により生じる感性の個人差の定量化を試み る.この乘離度を用いて, 乘離度の小さい個人差の影響を受 けにくい製品デザインや, 消費者属性に応じた製品デザイン の提案に役立てる.

このモデルは従来，機能性設計において誤差因子によるば らつきが小さくなるような制御因子の組合せを設定し，どの ような環境でも一定の機能を発揮するロバストな製品を生み 出すために用いられてきた。感性評価で機能性設計と同様の 見方をすることで，消費者属性を誤差因子と考え，評価のば らつきの小さい消費者属性による感性の違いに影響を受けな い，どのような消費者からも同じ評価の得られる製品デザイ ンを考えることができる，感性の共通性を活かした製品設計 ができると言える。

一方，交互作用モデルに対して感性デー夕を適用した例は 今までに見られていない，そこで，本研究では感性評価特有 の見方を提案する．鈴木ら［4]で明らかなように消費者属 性を標示因子と考えることで製品属性と消費者属性の交互作 用を分析し消費者の嗜好に合わせた製品提案をすることがで きる。本研究の交互作用モデルでは乘離パートで製品属性と 消費者属性の交互作用が表現されているので, 注目する消費 者属性に応じた製品属性の最適水準を決定することができ る. 感性の相違性を活かした製品設計ができると言える. また，消費者属性による製品デザインに対する嗜好の差別化 を行うことができるため, 結果として消費者カテゴリーの層 別を行うことができる，本研究では，消費者属性を誤差因子 と考え, 感性の共通性に着目した手法を手順 1 , 標示因子と 考え感性の相違性に着目した手法を手順 2 とする，以下では その詳細を述べる。 


\section{（a）手順 1 (感性の共通性に着目した製品デザイン)}

消費者属性を誤差因子と考え，感性の共通性に着目した製 品デザインの提案方法について述べる。

(1) 乘離度を小さくする製品属性の水準の決定

製品属性 $x_{i}(i=1,2, \cdots, g)$ の水準数を $m_{i}$ とする．このとき, $X_{i}$ を製品属性 $x_{i}$ の持つ $m_{i}$ 水準の集合と考え $X_{i}=\left\{X_{i}^{1}, X_{i}^{2}, \cdots, X_{i}^{m_{i}}\right\}$ と定義する。 $(i=1,2, \cdots, g)$ のとき $g$ 個の製品属性がある といえ, これらによる組合せ，つまり製品の数は全部で $\prod_{i=1}^{g}\left|\boldsymbol{X}_{\boldsymbol{i}}\right|=\prod_{i=1}^{g} m_{i}$ 通り考えられる.

消費者属性についても同様に考える. 消費者属性 $z_{j}(j=1,2$, $\cdots, h)$ の水準数を $n_{j}$ とする。 このとき， $\boldsymbol{Z}_{j}$ を消費者属性 $z_{j}$ の持つ $n_{j}$ 水準の集合と考え $\boldsymbol{Z}_{j}=\left\{Z_{j}^{1}, Z_{j}^{2}, \cdots, Z_{j}^{n_{j}}\right\}$ と定義する. また，本論文では $Z_{j} に$ 含まれる消費者属性 $Z_{j}^{1}, Z_{j}^{2}, \cdots, Z_{j}^{\mathrm{n}_{j}}$ 持つ消費者属性の集合をそれぞれ $\boldsymbol{Z}_{j}^{1}, \boldsymbol{Z}_{j}^{2}, \cdots, \boldsymbol{Z}_{j}^{\mathrm{n}_{j}}$ と定義する.

$j=1,2, \cdots, h$ のとき $h$ 個の消費者属性があるといえ, これ らによる組合せ,つまり消費者カテゴリーの数は全部で $\prod_{j=1}^{h}\left|\boldsymbol{Z}_{j}\right|=\prod_{j=1}^{h} n_{j}$ 種類考えられる.

ここで，消費者属性による評価のばらつきが小さい製品属 性を求めるため式 (2.4) に注目する。 この部分は消費者カテ ゴリーの違いにより值が変化する部分である。 $\prod_{i=1}^{g}\left|\boldsymbol{X}_{i}\right|$ 通り の製品の集合を $\boldsymbol{X}$ とする。ある製品 $k \in \boldsymbol{X}$ について考えたと き, $\prod_{j=1}^{h}\left|Z_{j}\right|$ 種類の消費者カテゴリーによりそれぞれ評価が 下されていることがわかる．また， $\prod_{j=1}^{h}\left|Z_{j}\right|$ 種類の消費者力 テゴリーの集合を Zとする，ある製品 $k \in X$ が持つ製品属性 の水準と, ある消費者カテゴリー $l \in \boldsymbol{Z}$ に打ける消費者属性 の水準をそれぞれ $x=\left(x_{1}, x_{2}, \cdots, x_{g}\right), z=\left(z_{1}, z_{2}, \cdots, z_{h}\right)$ に対し てダミー変数を対応させ総乘離を式 (2.4) に基づき算出する. そして製品 $k$ に対する総乘離に関して最大值を $\max D(k, z)$, 最小值を $\min D(k, z)$ とする。

製品 $k$ について対象としている消費者カテゴリーの集合 $\boldsymbol{Z} に$ おける総乘離の最大值と最小值の差を乘離度 $\sigma_{k, Z}$ と定義する.

$$
\sigma_{k, Z}=\max _{z \in \mathrm{Z}} D(x, z)-\min _{z \in \mathrm{Z}} D(x, z)
$$

評価值と乘離度, 総乘離の関係は図 1 の通りである。総乘 離は評価值と平均值の差といえる。図1からもわかるように 乘離度が小さい製品が消費者による評価のばらつきが小さい 製品ということができる，複数の消費者が混在する消費者

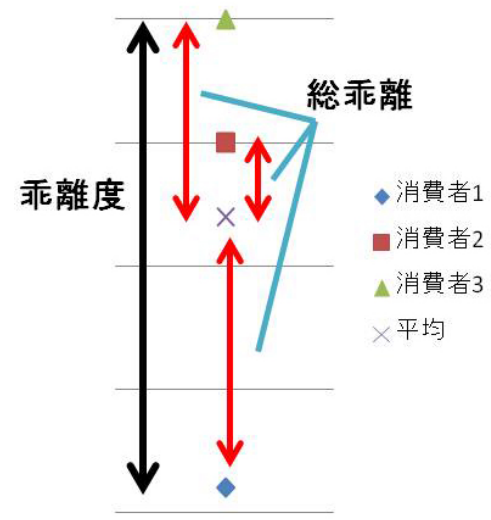

図1 総乘離と乘離度のイメージ
カテゴリーについて考えたとき，靟離度が最小の製品がその カテゴリー内で評価のばらつが小さい製品となる，消費者力 テゴリーの集合 $\boldsymbol{Z}$ に対する乘離度の中から $\sigma_{k Z}=\min _{x \in X} \sigma_{x, Z}$ となるときの製品 $k$ の持つ水準が $\boldsymbol{Z}$ に対して評価のばらつき が最も小さい製品属性の水準となる. $\min _{x \in X} \sigma_{x, Z}$ が複数ある 場合は全て (2)・ (3)の操作を行い評価值の算出する。 そして, 最も評価值の高い製品の水準を選択することとする.

(2) 平均パートに打ける水準の決定

乘離パートだけで全ての製品属性が定まるとは限らない. 水準が(1)で定まらなかった製品属性で平均パートに存在する 属性については(2)で水準を決定する. 決定の仕方であるが, 評価值が目標值へ近づくような水準を選べば良い．製品 $k \in \boldsymbol{X}$, に対する $l \in \boldsymbol{Z}$ の評価值を $y_{k, l}$ としたとき $y_{k, l}$ を式 (2.6) で表現する。ここまでで決定した水準を変数部分に代入し評 価値を算出する。

$$
y_{k, l}=L(k)+D(k, l)
$$

(3) 評価值の算出

(1)，(2)からわかるように製品 $k$ に対する評価值は $\prod_{i=1}^{g}\left|\boldsymbol{Z}_{j}\right|$ 個 ある、しかし, 評価值が複数あると消費者カテゴリーZにおけ る製品の評価指標が一つに定まらないため, 本研究では消費者 カテゴリー Zに対する評価值の平均を $\mu_{k, Z}$ とし式 (2.7) で定義 し, 乘離度とともに製品デザインの重要な指標として用いる.

$$
\mu_{k, \boldsymbol{Z}}=\left(\sum_{\mathrm{j}=1}^{\prod_{j=1}^{g}\left|Z_{j}\right|} y_{k, j}\right) / \prod_{j=1}^{g}\left|Z_{j}\right|
$$

乘離度 $\sigma$ と評価值 $\mu$ を用いることでカテゴリーにおけるばら つきが小さくなりかつ，評価值が目標值に近くなるような製 品を考えることが感性の共通性に着目した製品デザインを提 案する目的である.

\section{（b）手順2（感性の相違性に着目した製品デザイン）}

式 (2.4) では製品属性 $x=\left(x_{1}, x_{2}, \cdots, x_{g}\right)$ と消費者属性 $z=\left(z_{1}, z_{2}, \cdots, z_{h}\right)$ の交互作用が $z_{1} \times z_{2}, \cdots$ という形で表現され ている. 分析を進める際には式 (2.2) を変数増減法により変 数選択するが，そこで残った変数は評価值へ大きく関わって いる変数であるため消費者属性が評価に影響を与えている箇 所とわかる．消費者属性を標示因子と考えることで消費者属 性に応じた製品属性を選ぶことができる箇所ともいえる。こ の性質を利用し，消費者属性で消費者を層別し，その層が好 む製品デザインを生み出すにはどのような製品属性を持つ製 品とすべきかを把握することができる，

(1) 乘離パートにある交互作用に注目

式 (2.4) で変数増減法により求めた製品属性と消費者属性 の交互作用を表す項より，交互作用を持つ製品属性をあげて いく，式には製品属性 $\times$ 消費者属性をはじめ，製品属性 $\times$ 消費者属性 $\times$ 消費者属性 $\times$ ‥といった様々なパ夕ーンの交互 作用が表れている。 そこで, 製品属性と交互作用を持つ消費者 属性を $n$ パターンあるとしたとき, パターン 1 (製品属性 $\times z_{1}$ ), パターン $2\left(\right.$ 製品属性 $\left.\times z_{2}\right), \cdots$, パターン $n\left(\right.$ 製品属性 $\times z_{1} \times$ $\left.z_{2} \times \cdots\right)$ と考えることでそれぞれ(2)以降の分析を進めて行く. 
(2) 各パターンによる分析

例えば，パターン 1 (製品属性 $\times z_{1}$ ) のとき $z_{1}$ を性別と考 える，このとき水準 (男性, 女性) で消費者を層別する。評 価值の平均值と製品属性の水準から, 男性が好む製品属性の 水準, 女性が好む製品属性の水準をそれぞれ考え, 性別の違 いによりデザインを差別化するような製品を考えていく．

以上の操作をパターン $n$ まで全て行う。何パターンも行う ことで様々な層別方法が検討できる.

\section{3 感性にあった製品デザインの提案手順}

本研究の目的は消費者属性の違いを考慮して, 高い評価を 得ることができる製品デザインを提案することである，その ために, 直積実験を計画し, 式 (2.2)の $\mu_{(x, z)}$ に当てはまる評 価值をアンケートなど用いることで収集する。 アンケートの 回答結果や回答者 (消費者) のカテゴリーをインプットと し，目的を達成するために消費者カテゴリーの層別とそれぞ れの層内に拈いて評価のばらつきが小さく評価の高い製品 デザインをアウトプットとして提案する，そのための手順を 図2の手順を提案し，その詳細を以下に記述する.

Step 0：初期設定

初期設定として, 製品の良し悪しを決める評価值の基準と なる目標值を設定する。また，全ての消費者を一つのカテゴ リー Zと設定しておく.

Step 1 ：全ての消費者に好まれる製品の提案

全ての消費者を一つのカテゴリー $\boldsymbol{Z}$ とし, カテゴリー内で の評価のばらつきが小さい製品を手順 1 により提案する.

手順 1 を実行すると評価值が算出されるが, この評価值が高 いとも限らない，そこで，あらかじめ定めた目標值と比較す
る，超えてればその製品は消費者の感性を満たすには十分な ものということができる.

一方，超えていない場合は消費者カテゴリーを細分化する ことで高い評価を得る製品を提案することを考える.

Step 2：消費者カテゴリーの差別化

全ての消費者を一つの製品で満足させることができないた め, Step 2へ手順を進めている．消費者を層別し製品提案を 行うことで，感性に適した製品を提案することを考える。 層別方法として手順2を用いることで, 消費者属性に応じて 消費者の差別化を行うことができる，どの消費者属性をもと にカテゴリーの差別化を行うかであるが，図2で示したよう にパターン 1 , パターン $2, \cdots$, パターン $n$ と製品属性と交 互作用を持つ消費者属性の数だけ考える，層別方法は様々な やり方が存在しており，アプローチが異なれば最終的な消費 者カテゴリーや提案される製品も変わってくる．多くのアプ ローチ方法を考えることができる本研究のモデルの特性を活 かして，より評価の高い製品を考えていく.

図2のようにStep 2 では消費者属性 $\boldsymbol{Z}_{1}$ により差別化を行う パターン 1 で $\boldsymbol{Z}_{1}^{1} \sim \boldsymbol{Z}_{1}^{n_{j}}$ へと Zをカテゴリー分けし，それぞれの カテゴリーに対して最適な製品属性を選択する。分けられた カテゴリーではどのような製品の評価が高くなるかを知らな くては製品提案を行うことができない. そこで, 手順 $2 て ゙$ 選択 された製品属性はそのまま利用し, 手順 1 を用いてカテゴリー 間で乘離度を最小にする製品とその評価值を算出する。目標 值を上回らなければ，まだ消費者の感性にあった製品が生み出 せないていないことがわかるので, さらにカテゴリーを絞りこ む必要があるためStep 3へ進む。 また, 図2のようにStep 2 では同様の操作をパターン $2, \cdots$, パターン $n$ についても行う.

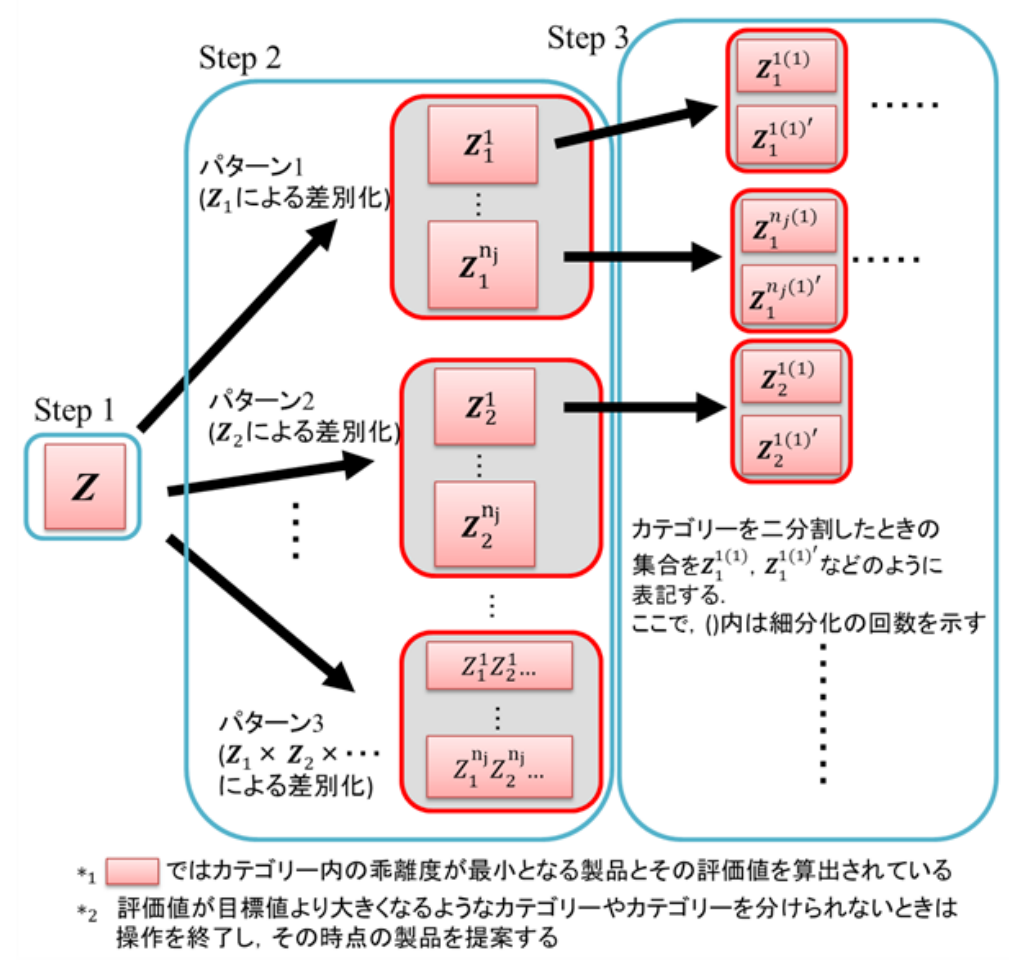

図2 目標值を満たす製品デザインを生み出す手順 
なお，パターンによっては消費者カテゴリーの中に一種類 の消費者属性しか含まれないものもある。例えば, 図2で示 したパターン $n$ のように $\boldsymbol{Z}_{1}^{1} \boldsymbol{Z}_{2}^{1} \ldots$ や $\boldsymbol{Z}_{1}^{n_{j}} \boldsymbol{Z}_{2}^{n_{j}} \ldots$ はこれ以上細分 化できない消費者カテゴリーにこの時点で差別化される場合 もある。この場合はこの消費者属性に対して最適な製品を提 案する。

Step 3 ：消費者カテゴリーの細分化

Step 2の時点では評価值が目標值を上回っていないため, 消費者カテゴリーをさらに細分化していく，そして，それぞ れのカテゴリーで手順 1 を用いて製品とその評価值を算出す る.カテゴリー分けは, 図2のように細分化されたカテゴリー で提案された製品の評価值が目標值を上回るか, これ以上 細分化できなくなるまで繰り返す。細分化の基準であるが, カテゴリーに含まれる要素の数は均一である必要はない. カテゴリー間のばらつきが小さくなるように評価值の大小で 分割したり，評価值の分布を考え，かたまっている值とはず れ值で分割したりと状況に合わせて基準を定め考える.

また，細分化していく際にもパターン 1 〜パターン $n$ によ る差別化を反映させなくては, 消費者を差別化した意味が薄 れてしまうため, 各パターンで選択されたそれぞれのカテゴ リーで提案される製品が持つべき製品属性は常に変えないこ とに注意する。

\section{Step $4:$ 製品の比較}

図2のように消費者カテゴリーの層別方法は $n$ 個のパ夕ー ンに分岐できる。つまり，初期設定として考えた $\boldsymbol{Z} に$ 含まれ る消費者属性 $l \in \boldsymbol{Z}$ における製品はパターンの数だけ存在し ている。そこで，最終的に図3のように各パターンで出た 製品の評価值を比較することで，より感性評価の高い製品を $1 の$ 感性に適した製品として提案する.

この提案手順は以下の $2 つ の$ 点で有効である.

(1) カテゴリー分けの基準を決めることができる

図2のプロセスを経ずにカテゴリー分けを行い，製品のデ ザインを提案することもできるが，どの程度カテゴリーを考 え，何種類の製品の設計をすれば良いかの基準は明確にでき ない，全体を一つのカテゴリーとして段階的にカテゴリー分 けを行うことで，探索的にカテゴリー分けの基準を定めるこ とができる。

(2) 消費者属性の感性の違いを活かした製品提案ができる

手順 2 からわかるように本研究のモデルでは感性の相違性 に着目できるという特徴がある。図2のプロセスを踏むこと

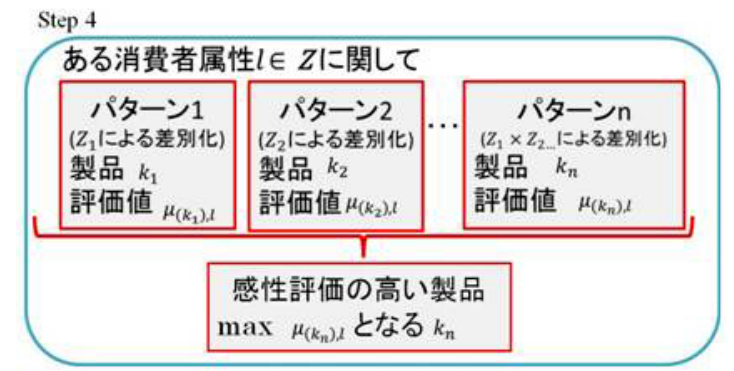

図3 ある消費者属性において最も感性評価の高い製品提案
で, Step 2で層別した消費者属性による差別化により生まれ た差が最後まで考慮される，消費者属性による違いを考えた 製品提案を行うためには提案手順を踏むことが有効である。

\section{3. 眼鏡を対象とした製品デザイン}

\section{1 データ収集}

本研究では眼鏡を対象とした感性評価を考えていく，眼鏡 は視覚的に違いがわかるような製品属性を持つ製品で，価格 や機能性で製品の良し悪しが判断できないような製品である.

上田 [7] でも性別，年代によってフレームやレンズへの こだわりに違いがあると述べており，フレームやレンズは製 品のデザインに関わる製品属性である.

以上より，眼鏡は製品デザインの適用例として適した製品 だと考えられる。製品属性を伊藤ら［8］の眼鏡の認知部位 をもとに表 1 のように定め, 消費者属性は表 2 ように定める. 消費者属性に関して，本研究ではより一般的なものを選定し たが，より具体的な消費者属性を考慮することができれば, 消費者個々人の感性の個人差へと帰着することも可能であ る。また，表3のように $L_{18}$ 直交表へ因子を割り付け，以下 のアンケートを実施した。なお，図4はアンケートの一例で 直交表の製品No.1についてである.

•評価対象: 眼鏡 18 種類 (直交表にもとづきサンプルを選択) ・評価項目：おしゃれな↔おしやれでない

・評点方法 : S D法

（1-7 点で 1 点刻みに評価）

- 被験者 : 20 代(学生)の男性・女性, 20３0 代(社会人)男性・女性 40～50 代(社会人)男性・女性 それぞれ 2 人ずつ（計 12 名)

表1 製品属性一覧

\begin{tabular}{|c|c|c|c|}
\hline \multirow{2}{*}{ 製品属性 } & \multicolumn{3}{|c|}{ 水準 } \\
\hline & 1 & 2 & 3 \\
\hline$A:$ ふちの太さ & 太い & 細い & \\
\hline $\begin{array}{l}B: \text { :フレームの } \\
\text { スタイル }\end{array}$ & フルリム & ハーフリム & ツーポイント \\
\hline$C:$ フレームの形 & 長方形 & 逆台形 & 丸 \\
\hline $\begin{array}{l}D: \text { サド部分 } \\
\text { のデザイン }\end{array}$ & $\begin{array}{c}\text { フロントと異 } \\
\text { なる }\end{array}$ & $\begin{array}{c}\text { フロントと } \\
\text { 一体 }\end{array}$ & \\
\hline $\begin{array}{l}E: \text { フロント部分 } \\
\text { の色 }\end{array}$ & 茶色 & 黒 & 白系 \\
\hline
\end{tabular}

表2 消費者属性一覧

\begin{tabular}{|c|c|c|c|}
\hline \multirow{2}{*}{$\begin{array}{c}\text { 消費者 } \\
\text { 属性 }\end{array}$} & \multicolumn{3}{|c|}{ 水準 } \\
\cline { 2 - 4 } & 1 & 2 & 3 \\
\hline$P:$ 性別 & 男 & 女 & \\
\hline$Q:$ 年代 & 20 代学生 & $20 \sim 30$ 代社会人 & $40 \sim 50$ 代社会人 \\
\hline
\end{tabular}


表3 直交表の割り付け
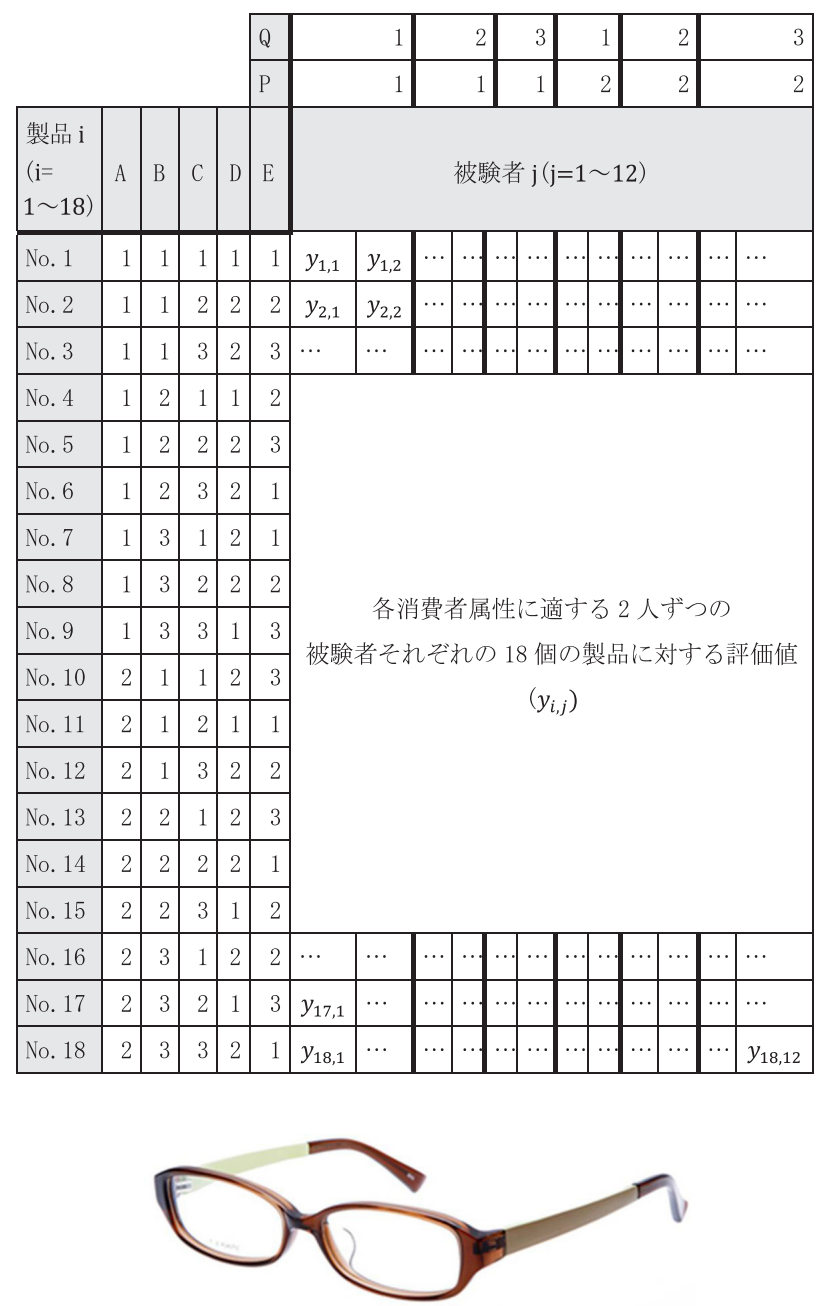

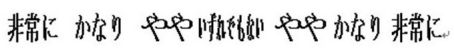

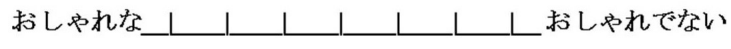

図 4 アンケートの一例

\section{2 製品属性と消費者属性の交互作用モデルの導出}

集めたデー夕を標準化し, 表4 と表 5 で示したダミー変数 を用いてモデルを導出すると式 (3.1) のようになる。

$y=0.01-0.06 x_{A}+0.14 x_{B}+2.00 \times 10^{-3} x_{C}-0.03 x_{D}+0.11 x_{E}$ $-\left(0.06+4.00 \times 10^{-3} x_{A}+0.24 x_{B}+0.07 x_{C^{-}} 0.18 x_{D^{-}}-0.04 x_{E}\right) z_{P}$ $+\left(0.03-0.08 x_{A^{-}} 0.27 x_{B}+0.10 x_{C}-0.10 x_{D}+0.15 x_{E}\right) z_{Q 1}$ $-\left(0.06+0.28 x_{A}+0.04 x_{B}+0.28 x_{C}-0.17 x_{D}+0.05 x_{E}\right) z_{Q 2}$

$-\left(4.00 \times 10^{-3}+0.03 x_{A^{-}}-0.06 x_{B}+0.06 x_{C}-0.01 x_{D^{-}}-0.16 x_{E}\right) z_{P} z_{Q 1}$ $-\left(0.02+0.07 x_{A}+0.16 x_{B}-0.20 x_{C}-0.05 x_{D}+0.10 x_{E}\right) z_{P} z_{Q 2}$

有用な交互作用を求めるためは AICが最小となるような変 数増減法を用いる。変数増減後の式が式 (3.2) である.

$$
\begin{aligned}
& y=4.63 \times 10^{-12}+0.14 x_{B}+0.11 x_{E} \\
& -\left(0.24 x_{B^{-}}-0.16 x_{D}\right) z_{P} \\
& -\left(0.29 x_{B^{-}}-0.12 x_{E}\right) z_{Q 1} \\
& -\left(0.32 x_{A}+0.23 x_{C}-0.11 x_{D}\right) z_{Q 2} \\
& -\left(0.14 x_{B}-0.17 x_{C}\right) z_{P} z_{Q 2}
\end{aligned}
$$

\begin{tabular}{|c|c|c|c|}
\hline \multirow{2}{*}{ 製品属性 } & \multicolumn{3}{|c|}{ 水準 } \\
\hline & 1 & 2 & 3 \\
\hline$A$ :ふちの太さ & $\begin{array}{c}\text { 太い } \\
\left(x_{A}=-1\right)\end{array}$ & $\begin{array}{c}\text { 細い } \\
\left(x_{A}=1\right)\end{array}$ & \\
\hline $\begin{array}{l}B: フ レ ー ム の \\
\text { スタイル }\end{array}$ & $\begin{array}{l}\text { フルリム } \\
\left(x_{B}=-1\right)\end{array}$ & $\begin{array}{c}\text { ハーフリム } \\
\left(x_{B}=0\right)\end{array}$ & $\begin{array}{c}\text { ツーポイント } \\
\left(x_{B}=1\right)\end{array}$ \\
\hline$C:$ フレームの形 & $\begin{array}{l}\text { 長方形 } \\
\left(x_{C}=-1\right)\end{array}$ & $\begin{array}{l}\text { 逆台形 } \\
\left(x_{C}=0\right) \\
\end{array}$ & $\begin{array}{c}\text { 丸 } \\
\left(x_{C}=1\right)\end{array}$ \\
\hline $\begin{array}{l}D \text { :サイ ド部分 } \\
\text { のデザイン }\end{array}$ & $\begin{array}{l}\text { フロントと異 } \\
\text { なる }\left(x_{D}=-1\right)\end{array}$ & $\begin{array}{l}\text { フロントと } \\
\text { 一体 }\left(x_{D}=1\right)\end{array}$ & \\
\hline $\begin{array}{l}E: \text { フロント部分 } \\
\text { の色 }\end{array}$ & 茶色 $\left(x_{E}=-1\right)$ & 黒 $\left(x_{E}=0\right)$ & 白系 $\left(x_{E}=1\right)$ \\
\hline
\end{tabular}

表4 製品属性のダミ一変数

表5 消費者属性のダミー変数

\begin{tabular}{|c|c|c|c|}
\hline 消費者属性 & $(P, Q)$ & $Z_{P}$ & $\left(Z_{Q 1}, Z_{Q 2}\right)$ \\
\hline 男 $(20$ 代学生 $)$ & $(1,1)$ & 1 & $(1,0)$ \\
\hline 男 $(20 \sim 30$ 代社会人) & $(1,2)$ & 1 & $(0,1)$ \\
\hline 男 $(30 \sim 40$ 代社会人) & $(1,3)$ & 1 & $(-1,-1)$ \\
\hline 女 $(20$ 代学生 $)$ & $(2,1)$ & -1 & $(1,0)$ \\
\hline 女 $(20 \sim 30$ 代社会人) & $(2,2)$ & -1 & $(0,1)$ \\
\hline 女 $(30 \sim 40$ 代社会人) & $(2,3)$ & -1 & $(-1,-1)$ \\
\hline
\end{tabular}

ここで, 消費者属性 $\mathrm{Q}$ に関しては2つの変数で表現されて いるため, 消費者属性 $\mathrm{Q}$ 製品属性の交互作用を考える際に は変数選択されなくても， $z_{Q 1}, z_{Q 2}$ どちらの積項に対しても共 通した製品属性の変数がある必要である. 式 (3.2)でいうと $x_{B} z_{Q 1}$ は選択されているが, $x_{B} z_{Q 2}$ は選択されていない.この 場合 $B \times Q$ の交互作用を考慮するために $x_{B} z_{Q 2}$ を追加する. 他の変数にも同様の操作を行いモデル式を再導出すると 式 (3.3) となる.

$$
\begin{aligned}
& y=4.63 \times 10^{-12}+0.14 x_{B}+0.11 x_{E} \\
& -\left(0.24 x_{B}-0.16 x_{D}\right) z_{P} \\
& -\left(0.08 x_{A}+0.27 x_{B}-0.10 x_{C}+0.09 x_{D}-0.15 x_{E}\right) z_{Q 1} \\
& -\left(0.28 x_{A}+0.04 x_{B}+0.28 x_{C}-0.16 x_{D}+0.05 x_{E}\right) z_{Q 2} \\
& -\left(0.06 x_{B}-0.06 x_{C}\right) z_{P} z_{Q 2} \\
& -\left(0.16 x_{B}-0.20 x_{C}\right) z_{P} z_{Q 2}
\end{aligned}
$$

\section{3 手順1, 手順2の適用}

\section{（a）手順1（感性の共通性に着目した製品デザイン）}

式 (3.2)の乘離パートは式 (3.4)である.

$D(x, z)=$

$-\left(0.24 x_{B}-0.16 x_{D}\right) z_{P}$

$-\left(0.08 x_{A}+0.27 x_{B}-0.10 x_{C}+0.09 x_{D}-0.15 x_{E}\right) z_{Q 1}$

$-\left(0.28 x_{A}+0.04 x_{B}+0.28 x_{C^{-}}-0.16 x_{D}+0.05 x_{E}\right) z_{Q 2}$

- $\left(0.06 x_{B}-0.06 x_{C}\right) z_{P} z_{Q 2}$

- $\left(0.16 x_{B}-0.20 x_{C}\right) z_{P} z_{Q 2}$

この適用例では評価值が高ければ高いほどおしゃれな 製品ということがわかる。 よって消費者カテゴリーの集合 $Z=\left\{P_{1} Q_{1}, P_{1} Q_{2}, P_{1} Q_{3}, P_{2} Q_{1}, P_{2} Q_{2}, P_{2} Q_{3}\right\}$ において乘離度が最小 になるかつ, 評価值が大きくなる製品属性の組合せとなるよ 
表6＼cjkstart嵊離度最小のときの変数の値

\begin{tabular}{|c|c|c|c|c|c|c|c|c|c|c|}
\hline 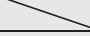 & \multicolumn{3}{|c|}{ 消費者属性 (変数) } & \multicolumn{5}{|c|}{ 製品属性(変数) } & \multirow[b]{2}{*}{ 総靟離 } & \multirow[b]{2}{*}{ 評価値 ～～} \\
\hline $\begin{array}{c}\text { 消費者属 } \\
\text { 性 }\end{array}$ & $z_{P}$ & $z_{Q 1}$ & $z_{Q 2}$ & $x_{A}$ & $x_{B}$ & $x_{C}$ & $x_{D}$ & $x_{E}$ & & \\
\hline$P_{1} Q_{1}$ & 1 & 1 & 0 & -1 & 1 & 1 & 1 & 1 & -0.097 & 0.157 \\
\hline$P_{1} Q_{2}$ & 1 & 0 & 1 & -1 & 1 & 1 & 1 & 1 & 0.014 & 0.269 \\
\hline$P_{1} Q_{3}$ & 1 & -1 & -1 & -1 & 1 & 1 & 1 & 1 & -0.142 & 0.112 \\
\hline$P_{2} Q_{1}$ & -1 & 1 & 0 & -1 & 1 & 1 & 1 & 1 & 0.064 & 0.319 \\
\hline$P_{2} Q_{2}$ & -1 & 0 & 1 & -1 & 1 & 1 & 1 & 1 & 0.097 & 0.348 \\
\hline$P_{2} Q$ & -1 & -1 & -1 & -1 & 1 & 1 & 1 & 1 & 0.067 & 0.322 \\
\hline
\end{tabular}

うな変数を代入する。 この例で以上を満たす $\sigma_{k, Z}=\min _{x \in X} \sigma_{x, Z}$ となる製品 $k$ を求めると， $k=A_{1} B_{3} C_{3} D_{2} E_{3}$ となる，このとき の各消費者属性に対する総乘離と評価值をまとめると表 6 の ようになる，表6より，このときの $A_{1} B_{3} C_{3} D_{2} E_{3}$ の乘離度は 以下の通りである

$$
\begin{aligned}
\sigma_{A_{1} B_{3} C_{3} D_{2} E_{3}, Z} & =\max D(x, z)-\min D(x, z) \\
& =0.097-(-0.142) \\
& =0.24
\end{aligned}
$$

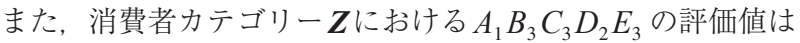
次のようになる

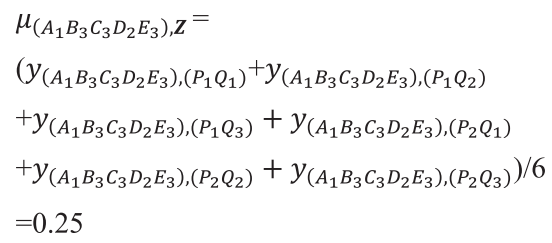

（b）手順2（感性の相違性に着目した製品と消費者の層別）

式 (3.4) より乘離パートで表現されている交互作用は表7 のようになる。パターンは全部で3つあり，詳細は以下のよ うになる。

パターン $1 ：$ 製品属性 $\times P($ 性別 $)$

表 7 より消費者属性 $P$ と交互作用を持つ製品属性は $B$ と $D$ である．製品属性 $B, D$ は製品評価へ影響を与える要因と考え られる。これらの製品属性について図5, 図6のように評価值 の平均値を縦軸にして消費者属性ごとの重要度を把握する.

パターン 1 では消費者属性 $P_{1}$ は $B_{1} D_{2}$ を持つ製品を, $P_{2}$ は $B_{3} D_{1}$ を持つ製品をそれぞれ好むことがわかる．性別で消費 者を層別し，男性・女性で好みを差別化した製品といえる。 パターン $2:$ 製品属性 $\times Q$ (年代)

表7 より消費者属性 $Q$ と交互作用を持つ製品属性は $A, B$, $C, D, E$ である。 パターン 1 と同様にして消費者属性 $Q_{1}$, $Q_{2}, Q_{3}$ が好む製品属性をまとめると表8のようになる. 年代で消費者を層別し, 学生・20～30代· 40～50代で好 みを差別化した製品といえる.

パターン 3 : 製品属性 $\times P \times Q($ 性別 $\times$ 年代 $)$

表7より消費者属性 $P \times Q$ と交互作用を持つ製品属性は $B, C$ である. パターン 1,2 と同様にして消費者属性 $P_{1} Q_{1}, P_{1} Q_{2}$, $P_{1} Q_{3}, P_{2} Q_{1}, P_{2} Q_{2}, P_{2} Q_{3}$ が好む製品属性をまとめると表 9 よ うになる。性別 $\times$ 年代つまり適用例で考えられる全ての消 費者カテゴリー6つで層別し，それぞれの好みが差別化され ている製品といえる. 表7＼cjkstart製品属性と消費者属性の交互作用

\begin{tabular}{|l|c|c|c|c|c|}
\hline \multirow{2}{*}{ 要因 } & \multicolumn{5}{|c|}{ 製品属性 } \\
\cline { 2 - 7 } & $A$ & $B$ & $C$ & $D$ & $E$ \\
\hline 製品属性 $\times P$ & & $\bullet$ & & $\bullet$ & \\
\hline 製品属性 $\times Q$ & $\bullet$ & $\bullet$ & $\bullet$ & $\bullet$ & $\bullet$ \\
\hline 製品属性 $\times P \times Q$ & & $\bullet$ & $\bullet$ & & \\
\hline
\end{tabular}

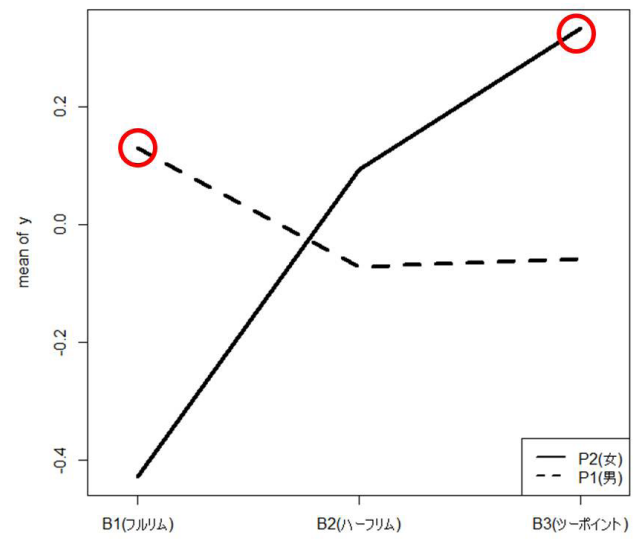

図５製品属性B と消費者属性Pの交互作用のグラフ

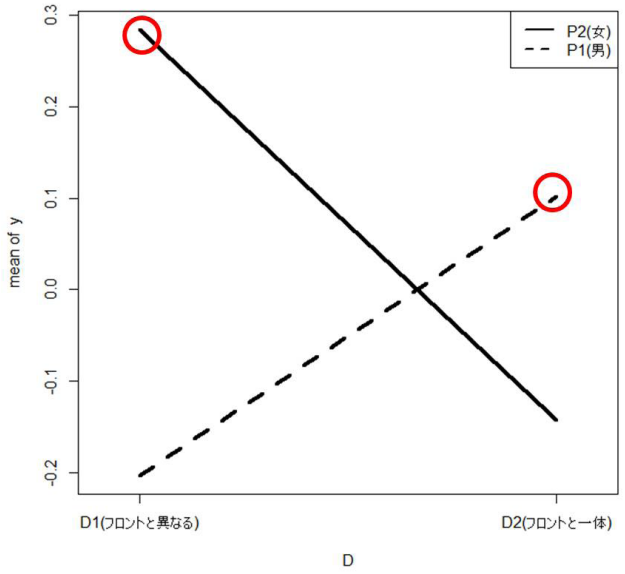

図6 製品属性D と消費者属性Pの交互作用のグラフ

表8 パターン2の結果

\begin{tabular}{|c|c|}
\hline 消費者属性 & 製品属性 \\
\hline$P_{1} Q_{1}(20$ 代学生・男 $)$ & $B_{1} C_{1}$ \\
\hline$P_{1} Q_{2}$ (20 30 代社会人.男) & $B_{2} C_{1}$ \\
\hline$P_{1} Q_{3}(40 \sim 50$ 代社会人. 男) & $B_{3} C_{1}$ \\
\hline$P_{2} Q_{1}(20$ 代学生 - 女 $)$ & $B_{2} C_{3}$ \\
\hline$P_{2} Q_{2}(20 \sim 30$ 代社会人・女） & $B_{3} C_{1}$ \\
\hline$P_{2} Q_{3}$ (40 50 代社会人 $\cdot$ 女 $)$ & $B_{3} C_{3}$ \\
\hline
\end{tabular}

\begin{tabular}{|c|c|}
\hline 消費者属性 & 製品属性 \\
\hline$Q_{1}(20$ 代学生 $)$ & $A_{1} B_{2} C_{3} D_{1} E_{3}$ \\
\hline$Q_{2}(20 \sim 30$ 代社会人 $)$ & $A_{1} B_{2} C_{1} D_{2} E_{3}$ \\
\hline$Q_{3}(40 \sim 50$ 代社会人 $)$ & $A_{2} B_{3} C_{3} D_{1} E_{3}$ \\
\hline
\end{tabular}

表9 パターン3の結果 


\section{4 感性にあった製品デザインの提案手順の適用例}

全ての消費者カテゴリーから同じような評価を得ることの できる製品については3.3で考えた。ここで初期状態 (Step 0) として消費者が満足する評価值を7段階評価の 5 点と設定 する，各消費者に扮ける5 点を示す標準化した值の平均值を 目標值とすると 0.54 点となる。目標值は高くすれば高くす るほど，より評価の高い製品を生むきっかけになる一方，

Step 1 での製品提案の数が少なくなり, 複数の層の消費者に またがって好まれる製品を提案しづらくなる，低ければ低い ほど, Step 1 で提案ができる製品が多くなるため, 層別回数 が少なくなる，つまり，多くの消費者カテゴリーに同時に好 まれる製品を提案できる可能性がある。また，初期状態では 消費者カテゴリーを全ての消費者を一つのカテゴリーと考え $Z=\left\{P_{1} Q_{1}, P_{1} Q_{2}, P_{1} \mathrm{Q}_{3}, P_{2} Q_{1}, P_{2} Q_{2}, P_{2} Q_{3}\right\}$ と定義する.

次に, Step 1 の操作である $A_{1} B_{3} C_{3} D_{2} E_{3}$ の評価值を算出す る. $\mu_{\left(A_{1} B_{3} C_{3} D_{2} E_{3}\right) Z}=0.25$ であり, 目標值へ届いていない. そこ で，感性評価の高い製品を生み出すために消費者をStep 2 に もとづき層別してみる.

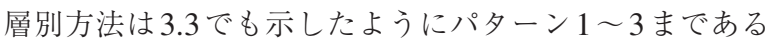
ため, これ以降の操作は全てのパターンで繰り返す必要があ る．本章ではパターン 1 を例に挙げて解析する，パターン 1 は 消費者を性別で層別している，そこで，消費者属性 $P_{1}$ (男性) を持つ集合 $\boldsymbol{Z}_{1}^{1}=\left\{P_{1} Q_{1}, P_{1} Q_{2}, P_{1} Q_{3}\right\}$ と消費者属性 $P_{2}$ (女性) を持つ集合 $\boldsymbol{Z}_{1}^{2}=\left\{P_{2} Q_{1}, P_{2} Q_{2}, P_{2} Q_{3}\right\}$ と集合を定義する。そし て，それぞれの集合に対して共通した評価を得られる製品を 考えていけば男性，女性にそれぞれ好まれる製品を生み出す きっかけとなる。それぞれのカテゴリーに対して乘離度が最 小となる製品とその評価值を算出すると表10のようになる.

表 10 より $\boldsymbol{Z}_{1}^{2}$ に関しては目標值に到達している. $A_{1} B_{3} C_{2}$ $D_{1} E_{3}$ は年代問わず女性全体に好まれる製品であると言え,

$\boldsymbol{Z}_{1}^{2}$ の分岐は終了する。一方, $\boldsymbol{Z}_{1}^{1}$ の製品の評価值は目標值に 到達していない。つまり, 男性全体に好まれるような製品は 発見できない。 なお図7 は $\boldsymbol{Z}_{1}^{1}$ で分析された製品のサンプルで ある，そこで趼はStep 3 に進み分岐を行う．Step 3 の分岐の

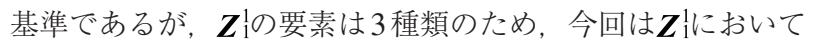
提案された製品に対して最も低い評価を示す消費者とそれ以 外で分岐する。それぞれの評価值と平均值の関係は図 8 の通 りである。

表10 性別で層別したときの乘離度と評価値

\begin{tabular}{|c|c|c|c|}
\hline 消費者カテゴリー & 製品 & 乘離度 $\sigma_{i, N}$ & 評価值 $\mu_{i, j}$ \\
\hline $\begin{array}{c}\boldsymbol{Z}_{\mathbf{1}}^{\mathbf{1}}= \\
\left\{P_{1} Q_{1}, P_{1} Q_{2}, P_{1} Q_{3}\right\}\end{array}$ & $A_{2} B_{1} C_{3} D_{2} E_{1}$ & 0.13 & 0.15 \\
\hline $\begin{array}{c}\boldsymbol{Z}_{1}^{2}= \\
\left\{P_{2} Q_{1}, P_{2} Q_{2}, P_{2} Q_{3}\right\}\end{array}$ & $A_{1} B_{3} C_{2} D_{1} E_{2}$ & 0.38 & 0.66 \\
\hline
\end{tabular}

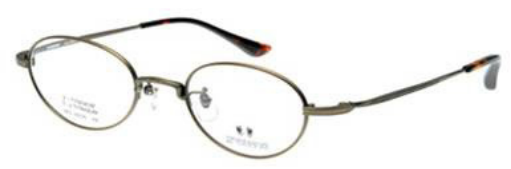

図7 $A_{2} B_{1} C_{3} D_{2} E_{1}$ のサンプル

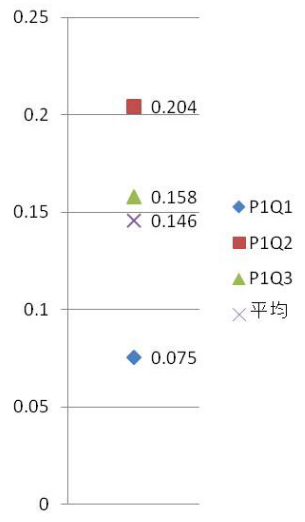

図8 製品に対する男性の評価値の図示

図 8 からもわかるように $P_{1} Q_{1}$ が最も評価值が低く, カテゴリー の乘離度を大きくし, 評価值 (平均值) を低くしている要素と

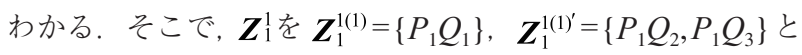
分割し $Z_{1}^{1(1)}, Z_{1}^{1(1)^{\prime}}$ に対する製品とその乘離度, 評価值を表 11 に示す， $Z_{1}^{1(1)}$ に関しては要素が一つなので乘離度0とする。

$Z_{1}^{1(1)^{\prime}}$ は目標值へ届いていないため, Step 2で今までのよう カテゴリーを $\boldsymbol{Z}_{1}^{\mathbf{1 ( 2 )}}=\left\{P_{1} Q_{2}\right\}, \boldsymbol{Z}_{1}^{\mathbf{1 ( 2 )}}=\left\{P_{1} Q_{3}\right\}$ とさらに細分化 し, 乘離度 ·評価值を算出する。 $Z_{1}^{1(1)} に$ 関しては, これ以上 集合を細分化できないため, Step 2 にもとづき，ここで製品 が提案される. 以上をまとめると結果は表 12 の通りである.

表10〜表12の結果を見比べてもわかるように $Z$ に含まれ ていた要素に関してカテゴリー内の乘離度は減少し, 評価值 は向上しているとわかる，また，消費者属性 $P_{2}$ (女性）に関 しては表10の時点でこれ以上層別する必要がなかったので 推移は $P_{1}$ のように細かくはないが, $P_{2}$ も含めた操作の評価 值と乘離度の推移をまとめグラフで表したのが図9である。 図9に扔けるZが全ての消費者から共通した評価の得られる 製品の評価值と乘離度を示す点である。評価值が目標值に到 達していないためここから層別を行った，その部分は図上に ある $Z_{1}^{1}, Z_{1}^{2}$ と枝分かれしているところで表現されている. $Z_{1}^{1(1)}, Z_{1}^{1(1)^{\prime}}, Z_{1}^{1(2)}, Z_{1}^{1(2)^{\prime}}$ 同様に目標値へ届いていない段階 から層別したことで枝分かれしてできた部分である。本研究 の指標として用いた評価值と乘離度をグラフ化することで, 層別した部分や層別後の好ましい製品の評価值を視覚的に表 現できた。図9のように $P_{1} Q_{1}, P_{1} Q_{2}, P_{1} Q_{3}$ と層別することで

表11 性別をさらに層別したときの乘離度と評価値

\begin{tabular}{|c|c|c|c|}
\hline 消費者カテゴリー & 製品 & 乘離度 $\sigma_{i, N}$ & 評価值 $\mu_{i, j}$ \\
\hline $\boldsymbol{Z}_{1}^{1(1)}=\left\{P_{1} Q_{1}\right\}$ & $A_{1} B_{1} C_{2} D_{2} E_{3}$ & 0 & 0.73 \\
\hline $\boldsymbol{Z}_{\mathbf{1}}^{\mathbf{1}(1)^{\prime}}=\left\{P_{1} Q_{2}, P_{1} Q_{3}\right\}$ & $A_{2} B_{1} C_{3} D_{2} E_{1}$ & 0.05 & 0.18 \\
\hline
\end{tabular}

表12 カテゴリーをさらに層別したときの乘離度と評価値

\begin{tabular}{|c|c|c|c|}
\hline 消費者カテゴリー & 製品 & 乘離度 $\sigma_{i, N}$ & 評価值 $\mu_{i, j}$ \\
\hline $\boldsymbol{Z}_{1}^{1(2)}=\left\{P_{1} Q_{2}\right\}$ & $A_{1} B_{1} C_{2} D_{2} E_{3}$ & 0 & 1.03 \\
\hline $\boldsymbol{Z}_{1}^{\mathbf{1 ( 2 ) ^ { \prime }}}=\left\{P_{1} Q_{3}\right\}$ & $A_{2} B_{1} C_{3} D_{2} E_{1}$ & 0 & 0.19 \\
\hline
\end{tabular}




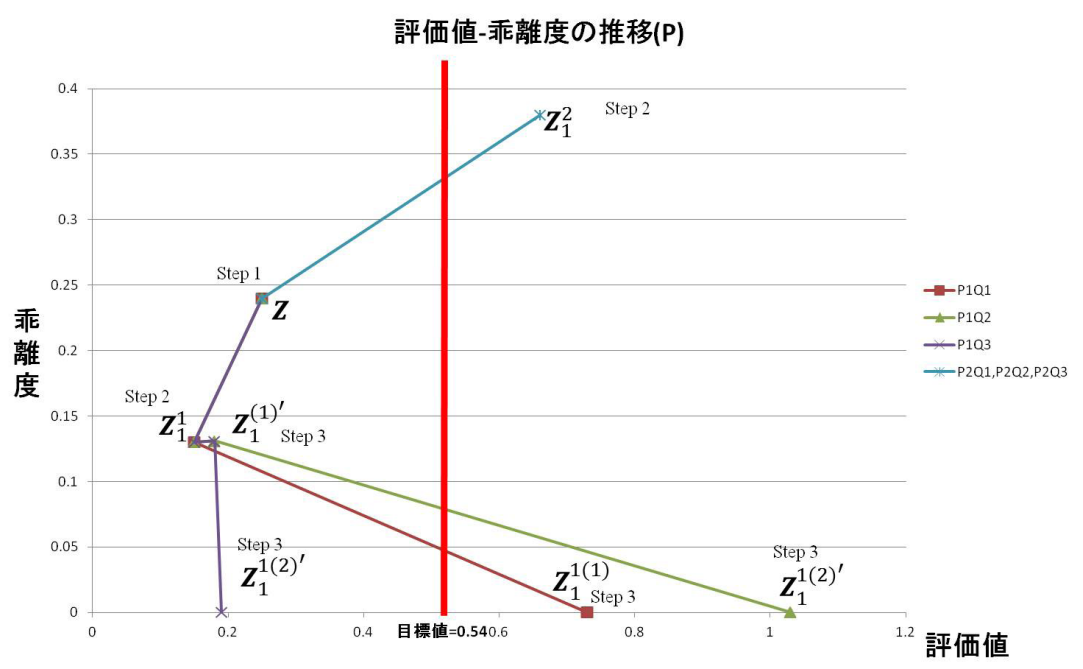

図9 パターン1における評価值-乘離度の推移

乘離度を小さくし，評価值が大きくなる推移が個人差の小さ い高評価の得ることができる製品を生み出すことができた。 中には $P_{2} Q_{1}, P_{2} Q_{2}, P_{2} Q_{3}$ のように層別することで乘離度が大 きくなるものもある。しかし， $P_{2}$ を持つ女性の消費者属性 を取り上げたとき評価の高い製品を生み出すためにはばらつ きは大きくなる。一方，このとき評価值は大きく上昇したこ とから乘離度は増加しても結果として感性評価を高める製品 を生み出すことができる。乘離度と評価值どちらを重視する かは設計者の意思決定にゆだねられる点でもある.

以上の結果より，パターン 1 のようにまず性別で層別した とき，性別で好みが別れるような製品を考えていたことにな るが，そのとき男性は複数のカテゴリーに共通して好まれる 製品は提案できなかった，しかし，女性は年代に関係ない製 品デザインを提案できた，消費者カテゴリーそれぞれに対し て感性評価が高くなるような製品は提案できた。

パターン 2 , パターン3でも同様のことを行うと. 年代で 好みが別れるような製品や性別 $\times$ 性別（全カテゴリー）で好 みが別れるような製品を提案できる。どの部分で差別化する のか, ある消費者属性で最も感性評価を高める結果が得られ るか, Step 4 に基づきパターン 1〜3で算出したそれぞれの 值を比較して考える必要がある.

例えば $P_{1} Q_{1}$ のカテゴリーにおいてパターン 1 ～3で提案さ れたそれぞれの製品に対する評価值に関しては図10のよう

ある消費者属性 $P_{1} Q_{1} \in Z$ に関して

\begin{tabular}{|c|c|c|}
\hline $\begin{array}{l}\text { パターン1 } \\
\text { (性別による差別化) } \\
\text { 製品 } A_{1} B_{1} C_{2} D_{2} E_{3} \\
\text { 評価値 } 0.73\end{array}$ & $\begin{array}{l}\text { パターン2 } \\
\text { (年代による差別化) } \\
\text { 製品 } A_{1} B_{2} C_{3} D_{1} E_{3} \\
\text { 評価値 } 0.54\end{array}$ & \begin{tabular}{l}
\multicolumn{1}{c}{ パターン3 } \\
(性別 $\times$ 年代による差別化) \\
製品 $A_{1} B_{1} C_{1} D_{2} E_{3}$ \\
評価値 0.68
\end{tabular} \\
\hline \multicolumn{3}{|c|}{$\gamma$} \\
\hline & \multicolumn{2}{|c|}{$\begin{array}{c}\text { 感性評価の高い製品 } \\
A_{1} B_{1} C_{2} D_{2} E_{3}\end{array}$} \\
\hline
\end{tabular}

図 $10 \quad P_{1} Q_{1}$ における評価値の比較
になる，性別において差別化するパターン 1 で生み出された デザインを持つ製品が最も評価が高いとわかる． $P_{1} Q_{1}$ (男子 学生）は打しゃれな眼鏡に対して性別により差別化したデザ インを持つ製品, つまり女性が好むようなデザイン要素を考 慮しない製品を選ぶ傾向があるということが考察できる。

性別 $\times$ 年代で差別化したパターン 3 は始めからこれ以上 細分化することのできない消費者カテゴリーそれぞれに対し

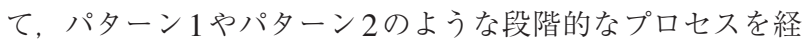
ずに製品提案がなされた例である。 カテゴリーを絞り効率的 に製品をできるともいえるが，パターン1のように性別によ る属性の差を考慮し, 段階的な手順を踏んだ製品の方が良い より評価を得ることのできる製品が提案できることがわか る.いくつかのパターンに分け, それぞれ手順通りプロセス を踏んで製品提案することの良さとも言える.

図 11 と図 12 はそれぞれパターン 1 とパターン 3 で提案さ れたサンプル図である。比較すればわかるように形の違いが 同じ消費者属性にとってもたらす評価が異なることを視覚的 に知ることができる。

以上のように分析を通して, 製品属性と消費者属性の交互 作用に着目することで，ある消費者属性に対して好ましい製 品属性が決定できる，適用例ではまず，全ての消費者属性に

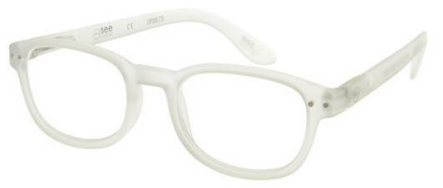

図11 $A_{1} B_{1} C_{2} D_{2} E_{3}$ のサンプル

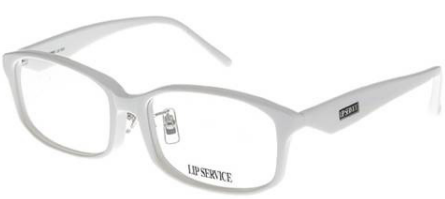

図12 $A_{1} B_{1} C_{1} D_{2} E_{3}$ のサンプル 
対して好ましい製品を考えた。しかし，評価值が高くなかっ たこともあり，消費者カテゴリーを層別し，それぞれの層に 対して最適な製品を考えた。 その後, パターン 1 であれば, 性別で層別し, それでも男性は目標值を超える製品が提案で きなかったこともあり, さらに年代で層別していった，女性 は年代で層別しなくても，評価の高い製品を得られていた。

以上のように, 男子学生, 20～30代社会人男性, 40〜 50代 社会人男性, 女性と4つの層にカテゴリー分けすることでそ の層の好む製品属性を考慮しつつ最適な製品デザインを提案 できた，その点で，消費者属性の感性の違いにマッチするよ うな製品属性を対応させ，最適な製品を生み出している。 段階を踏むことで, カテゴリー内のばらつきを小さく, 感性 評価を高めるデザインを提案することができた，今回の実験 では被験者数は多いとはいえないが，被験者を多くしても 実験の繰り返しとして同様の分析ができる。

この研究で算出された評価值は, 製品属性間の交互作用を 考慮しているため, 製品を構成するいくつかの属性同士の 関係性が評価值へと反映されている。そその点で単純な製品属 性個々の総和による評価值ではないこともあり，新たなデザ インを生み出したときの市場での評価予測を行うことが可能 である。しかし, 予測值であるため, 提案された製品を市場 に提供するには, 被験者数を増やした市場検証が必要である.

\section{4. 結 論}

本研究では消費者属性と製品属性の感性に及ぼす交互作用 を統計的に分析し, 消費者カテゴリーの感性のばらつきを評 価している，その結果，消費者カテゴリーのばらつきを小さ くするデザインや消費者カテゴリー間で差別化するデザイン などを求めることができるようになった。 これらの情報を活 用することで, 消費者カテゴリーを設定し, 設定された消費 者カテゴリーの感性を引き出すデザインを予測することがで きる。

$\mathrm{SN}$ 比解析やコンジョイント分析などの従来手法では誤差 因子と制御因子の交互作用や誤差因子間の交互作用は全て 誤差として扱っていた。本研究では従来無視されていたこれ らの交互作用に注目することで, 消費者属性が製品属性の好 みにどのように影響を与えているか把握することができるよ うになった。 また従来の夕グチメソッドによる SN比解析や コンジョイント分析ではもとめられなかった消費者カテゴ リーごとの評価值の推定ができるようになり，製品属性，

消費者属性，またそれらの交互作用が評価に与える影響が明 確になった１章で挙げた齋藤ら［2］の因子分析やクラスター 分析による個人差考慮の例でも消費者の要求と製品の特徴を 結びっけるアプローチを行っているものの製品の具体的な評 価との関連性の分析までは行われていない. その点で本研究 の製品属性と消費者属性の交互作用モデルを用いた製品提案 では消費者の要求と製品の特徵について交互作用を分析する ことで具体的な消費者の感性評価を高める製品提案のアプ ローチまで言及することができている。
本研究で用いたモデル式を従来の機能性設計ではなく感性 項目に当てはめることで新たな知見が得られた。機能性設計 ではロバスト性を高めるためにばらつきを小さくすることに 焦点を当てている，一方, 感性項目ではばらつきを小さくし たいときは消費者属性を誤差因子とし，消費者の嗜好に合わ せた製品デザインを考えたいときは消費者属性を標示因子 とし，それぞれ適した形で消費者属性を扱うことで消費者の 感性の個人差を分析できる.

本研究では製品属性の水準に対する 3 水準のときはダミー 変数 $-1,0,1$ を 2 水準のときは $-1,1$ を用いてモデルを導出 している，適用例では製品属性を水準という計数值で表現し た. SN比解析やコンジョイント分析では属性は水準で考え なくてはならないがモデルは重回帰式で算出されるため, 例えば-1〜1の範囲で計量值としてフレームの太さを表現す ることも可能である。 そうすることによりフレームが太いか 細いかという2択のあいまいな尺度ではなく，太さを厳密に 消費者の好みに合わせてデザインすることができる。フレー ムの形や色といったものも同様である，また，計数值や計量 值によるデー夕を一つの式として同時に扱うことができる. 本研究では計量值を扱った実験は行っていないが, Widiyati ら［3］鈴木ら [4] で提案された方法では計量值を扱うこと ができないものであり，交互作用モデルを用いた解析の利点 ということができる.

本研究ではおしゃれな乡おしゃれでないという一つの感性 項目を扱うことで個人差を考慮した製品デザインを分析し た。しかし，消費者がどんなに扎しゃれと考えてもその消費 者が拈しゃれさを重視していなければ購入までつながらな い. おしゃれさという部分的な最適化を目指すのではなく, 知的さや誠実さといった様々な感性や, Yadavら [9]でも 述べられたように製造コストなども総合的に考え消費者が 購入したい製品を考えて行くべきである，つまり多特性にも 対応できるようモデルを拡張していくことが必要である. また，以上を行うことで消費者はどのような感性を重視した 眼鏡に対して購買意欲がわくのかを明確にすることへとつな がりより感性評価の高い製品を提案するきっかけとなると考 えられる。

\section{謝 辞}

眼鏡の画像を提供して下さった Oh My Glasses（株）に感謝 の意を表します。

\section{参 考 文 献}

[1] 小阪裕司：「感性」のマーケティング 心と行動を読み解 き, 顧客をつかむ, PHP研究所, 2006 .

[2] 齋藤牧子, 和田裕一：携带電話の外観色の印象評価におけ る個人差分析, 感性工学会論文集, 11(1), pp.47-53, 2012.

[3] K. Widiyati, H. Aoyama: Taguchi Method for a Robust Design in Aesthetic (A PET Bottle Shape Case Study), 
設計工学, 47(12), pp.587-595, 2012.

[4] 鈴木秀男, クンティダ・テーチャワォラスインサグン, 圓川隆夫： 外側配置を導入したコンジョイント分析とその商品企画へ の応用, 日本経営工学会論文誌, 47(4), pp.257-264, 1994.

［5］高橋武則, 河村敏彦: 多水準をもつ誤差因子間の交互作用 を考慮した望目特性のロバストパラメータ設計, 統計数理 研究所, Research Memorandum, 1160, pp.1-11, 2012.

［6］河村敏彦, 高橋武則：統計モデルによるロバストパラメー 夕設計, 日科技連出版社, 2013 .

[7］上田太一郎：眼鏡のこだわりを科学する, 情報処理学会第 51 回全国大会講演論文集, pp.359-360, 1995.

［8］伊藤弘樹, 中村千枝, 井上勝雄, 関口彰 : ラフ集合を用い た女性向けメガネデザインの分析, 感性工学研究論文集, 6(2), pp.11-18, 2006

[9] H.C. Yadav, R. Jain, A.R. Singh, P.K. Mishra: Aesthetical design of a car profile: a Kano model-based hybrid approach, The International Journal of Advanced Manufacturing Technology, 67(9), pp.2137-2155, 2013.

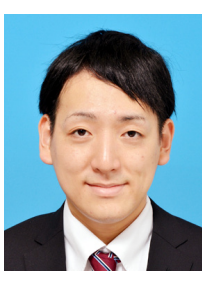

\section{市川 雄一朗 (学生会員)}

2015年 青山学院大学理工学部経営システム工 学科卒. 現在, 東京工業大学大学院社会理工学 研究科経営工学専攻修士課程在学中. 生産管 理及び顧客満足度向上に関する研究に従事. 日本感性工学会, 日本経営工学会, 日本品質 管理学会各会学生会員. 2015 年 日本経営工学会優秀学生賞受賞.

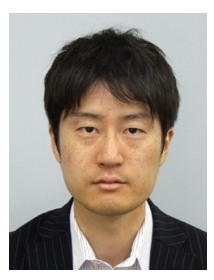

\section{齊藤 史哲 (非会員)}

2009年 東京工業大学大学院総合理工学研究 科知能システム科学専攻修了, 博士 (工学). 同大学精密工学研究所研究員などを経て, 2011 年より青山学院大学理工学部経営シス テム工学科助手, 2013 年より同助教. 知的 情報処理 (学習・エージェントモデルなど) に関する研究に従事. データマイニングの周辺技術に興味を持つ。

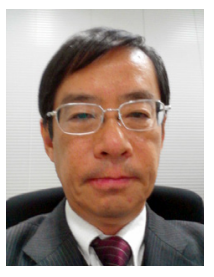

\section{石津 昌平 (正会員)}

1980年 広島大学大学院工学研究科博士後期 課程修了. 青山学院大学理工学部経営システ ム工学科教授. 工学博士. システム評価理論, 品質経営システム, 品質管理のための分析技 術, ラフ集合理論, 感性工学に関する研究に 従事. 日本感性工学会, 日本品質管理学会, 日本経営工学会, 計測自動制御学会, 日本経営情報学会各会員. 